\title{
A Linguistic Stylistic Study of Wole Soyinka's Night and Death in the Dawn
}

\author{
Nneoma Udeze, Chinenye Udeze \& Dereck-M. A. Orji \\ http://dx.doi./org/10.4314/ujah.v18i3.6
}

\begin{abstract}
Linguistic stylistics explores the linguistic features of a text; it is primarily concerned with the use of language and its effect in a text. This study is aimed at analyzing the language structure/system of Wole Soyinka's 'Night' and 'Death in the Dawn' to render a linguistic description, that is, identifying the linguistic deviant features of Soyinka's poems and describing how they deviated from the known rules to create effect. Some aspects of Niazi \& Gautam's (2010) framework, as well as Onwukwe's (2012) concept of foregrounded irregularities at the lexical, syntactic and semantic levels were adopted in the analysis of the data collected from a selection of deviant words and structures in the poems. Findings reveal that the syntactic level has the most deviant structures while the lexical level has the least deviant lexemes and that the language system of Wole Soyinka's poems deviated in ways that make words: violate the class to which they originally belong, inflect words which do not require inflections, create compounds not seen in the lexicon of the language, make structures violate the selectional restriction and category rule and give rise to figurative language. In conclusion, the choice of words in a literary work is very important as it creates certain effects on the readers of that work which is what Soyinka accomplished by deviating from the known linguistic norms. This research hopes to contribute to the understanding of Soyinka's poems and serve as a
\end{abstract}


reference point for scholars who wish to carry out a similar research.

\section{Introduction}

Style is the basic thing which gives uniqueness to every writer. Stylistics is derived from style and could be said to be a combination of style and linguistics. It is the scientific study of style; it is also the study of variations in language use. Stylistics according to Syal \& Jindal (2010) is that branch of linguistics which takes the language of literary texts as its object of study.

Stylistics is very important in literature because each literary text represents an individual's use of language which reflects his unique personality, thoughts and style. It helps to identify how and why a text has deviated. 'The goal of most stylistics is not simply to describe the formal features of texts for their own sake, but in order to show their functional significance for the interpretation of the text; or in order to relate literary effects to linguistic 'causes' where these are felt to be relevant' (Nordquist, 2015). Linguistic stylistics explores the linguistic features of a text. It is primarily concerned with the use of language and its effect in a text. It has to do with a stylistic study that relies heavily on the scientific rules of language in its analysis.

\section{About the poems}

Soyinka's (1976: 119) 'Night' is a poem written in triplets with the first and third lines of each stanza rhyming. It has five stanzas and fifteen lines. The poet describes nightfall and its effect on him. Soyinka's (1967: 64) 'Death in the Dawn', on the other hand, is a free-verse poem in seven stanzas and thirty-five lines of variable length. It is a poem that presents itself in a monologue, and addresses the reader as a "traveler", and a narrative account of life 
as a journey and a form of passage. Although it sounds like a form of lyric, the title "death" might be expected to take place in the evening but announces the contradictory concepts the poem will explore.

\section{Review of literature}

Concepts like style, stylistics and linguistic stylistics, related to the topic under discussion is reviewed here.

\section{Style}

Style is a difficult concept to define accurately because of the different views people have about it. That is to say that style as a concept has no single accurate definition and as such is defined differently by different scholars. Adejare (1992) makes this clear when he said that style is an ambiguous term. An author decides to choose a particular way of writing a text because of certain ideas in mind which the author will want the readers of that text to understand; so, for every style in writing which creates an effect on a reader, there is a particular purpose to it.

Lawal (1997) describes style as an aspect of language that deals with choices of diction, phrases, sentences, and linguistic materials that are consistent and harmonious with the subject matter. He added that it involves the narrative technique of a writer in terms of choice and distribution of words and character. Leech \& Short (2007: 9) view style as the way in which language is used in a given context to portray a particular idea. Therefore style is the basic thing which gives uniqueness to every writer. The language of poetry is different from the language of other literary genres. Style is involved in both, spoken and written, literary and nonliterary types of language but it is particularly associated with written form of the literary texts. The definitions on style given by 
these different authors have the same meaning in that an authors' style greatly depends on the idea he/she has in mind which he/she is trying to pass across and this is achieved through a selection of certain words, phrases and sentences.

\section{Stylistics}

The word stylistics is derived from style. The study of the term stylistics has long been associated with literary criticism, and stylistics has been considered as a branch of literary criticism. Later on, focus moved from the study of the author's style to how meanings and effects are produced by literary texts. Thus, there was a critical need to change the field from a branch of literary criticism into a field on its own (UKEssays, 2015).

Stylistics is defined as the linguistic study of literary appreciation (Anagbogu, Mbah \& Eme, 2010). To further elaborate, Finch (2000: 189), says that stylistics is concerned with using linguistic methods to study the concept of style in a language. Carter (1988) is of the view that stylistics is a bridge (link) discipline between linguistics and literature. "It is a branch of linguistics which studies the features of situationally distinctive uses (varieties) of language, and tries to establish principles capable of accounting for the particular choices made by individual and social groups in their use of language", (Crystal, 2008: 460).

Stylistics aims to account for how texts project meaning, how readers construct meaning and why readers respond to texts the way that they do.

It studies how individuals make language choices in different situations for different purposes. It also tries to point out the rules guiding such choices made by individuals and describe them. In Seboek (1964), stylistics is defined as a concept that relies on linguistics in some way since style cannot be clearly defined 
without reference to grammar. It is the study of style used in literary and verbal language, and the effect the writer/speaker wishes to communicate to the reader/hearer; it tries to explain why individuals make particular choices in their use of language, such as socialization and the production and reception of meaning (Niazi \& Gautam, 2010: 3).

"Every time we use language we necessarily adopt a style of some sort: we make a selection from a range of syntactic and lexical possibilities according to the purpose of the communication" (Finch, 2000: 189). "The study of style has traditionally been the preserve of literary criticism, but since the rise of linguistics there has been a more systematic attempt to provide a 'linguistic' foundation for literary effects", (Finch, 2000: 189). This means that the study of style has always been restricted to the literary aspects, but with the evolution of time, style can be studied through a linguistic perspective and this is what this work tries to achieve.

\section{Linguistic Stylistics}

Linguistic stylistics focuses on linguistic theory. "It is about doing stylistic analysis in order to test or refine a linguistic model- in effect, to contribute to linguistic theory", (Jeffries \& Mclntyre, 2010 in UK Essays, 2015). Linguistic stylistics was introduced as a complementary approach to literary criticism where the linguistic study of texts was absent. It is different from literary criticism in that while literary criticism rests solely on the subjective interpretation of texts, linguistic stylistics concentrates on the 'linguistic frameworks operative in the text' (Ayeomoni, 2003: 177). This gives the critic a pattern to follow, what to look out for in a text, and his point of view can be verified statistically. 


\section{Poetry}

Wordsworth (nd) in Abrams (1981: 115) sees good poetry as "the spontaneous overflow of powerful feelings" and strong "emotion recollected in tranquility". "Poetry communicates human emotion; it is the voice of the heart", (Robbins, 1997). Poetry is used to express how we feel about particular situations in life. "In poetry, aesthetic effect cannot be separated from the creative manipulation of the linguistic code", (Leech \& Short, 2007: 2). Ike (2005: 110) asserts that the poet's choice of words (vocabulary) reflects his mood which could either be one reflecting harsh or short words, sad or light-hearted denotative or connotative words.

By denotative, we mean the exact/specific meaning of a text, and by connotative, we mean that which is implied by the text, i.e., a text suggesting something else which is not overtly written. In Malmkj $\square$ r (2002: 513), literary language and the language of poetry in particular is different from ordinary language for day to day use because of its highly patterned nature and the fact that it violates the rules of grammar and lexis.

\section{Theoretical Framework}

For the linguistic stylistic analysis of Soyinka's (1976: 119) 'Night' and (1967: 64) 'Death in the Dawn' in this study, the foregrounding theory, using the devices of deviation only, is employed. According to Niazi \& Gautam (2010: 107), the Prague School of linguists has termed "foregrounding" the differentiating factor between poetic and non-poetic language; its function being to attract the reader's attention towards the subject matter of the poem. Linguistic deviations are easily noticeable and so have a very important psychological effect on the reader. Those parts of the text which are heavily foregrounded have to be taken into account when interpreting a poem. We can understand a word, 
phrase or sentence, which is linguistically deviant by comparing it with the normal paradigm. This means that a poet violates the rules of a language in order to create effect and this effect can be understood by comparing it with the normal norms of that language.

Following what Niazi \& Gautam (2010) and Onwukwe (2012) stated, deviations at the different levels of linguistic organization were selected. These selections which form the framework of this study are as follows:

Lexical level- Lexis deals with the words/vocabulary of a language. Being able to recognize the different word classes, and their associations, and identifying the word patterns, idiomatic phrases, collocations, and so on, can be useful in interpreting the meaning of the text. Poetic diction refers to a distinct tendency of restricting the language of poetry to a specific kind of vocabulary. They (poetic vocabulary) are the words that form the foundation of every literary work. Violations of the rules of word formation to create new words give rise to lexical deviation. The significance of the words, their semantic possibilities, irony, emotional associations and other effects has to be deeply analyzed. The evocative power of words is determined by the particular connection between diction and imagery and context of usage (Niazi \& Gautam, 2010: 109).

Syntactic level- Syntax is the study of the structure of phrases, clauses and sentences. Grammatical (syntactical) deviation is a phrase containing a word whose grammatical class violates the expectations created by the surrounding words (Niazi \& Gautam, 2010: 107). Put simply, they are deviant sentences and structures, that is, sentences and structures that do not conform to the normal syntactic rules of their constructions in a particular language (Onwukwe, 2012: 14). 
As Onwukwe (2012: 50) stated, Category rule violation and collocational violation or selectional restriction rule are instances of syntactic deviation. Linguistic items are meant to function in their categories in a sentence. Category rule violation occurs when a word in a particular category (example, a noun or a verb) begins to function as a word belonging to another entirely different category (example, a pronoun or a noun). Collocation is used "to refer to the habitual co-occurrence of individual lexical items". Some lexical items exhibit a natural tendency to co-occur. When this habitual company is broken, we have collocational violation. For instance, when a lexical item that is [+animate], [+human] cooccurs with a lexical item that is [-animate], a breach of collocation rule has taken place.

Semantic level- Semantics is the study of the meaning of morphemes, words, phrases and sentences. Meaning gets foregrounded through the selection of lexical items that do not usually go together in a context. Semantic deviations occur when the meaning of words violates the expectations created by the surrounding words. They usually violate the rules of selectional restrictions which are the semantic restrictions that a word imposes on the environment in which it occurs (Niazi \& Gautam, 2010: 107). According to Onwukwe (2012: 53), they are deviant because the meaning in them is not conveyed through literal meaningfulness. Semantic deviations are the figures of speech that abound in the language of literature (Onwukwe, 2012: 53) like;

a. Personification- This is giving a human quality to objects and things. For example, 'the cloud clapped in the sky' (Onwukwe, 2012: 21).

b. Simile- Here, two unlike things are compared using 'like' or 'as' to point out their similarity. For example, 'I wandered lonely as a cloud' (Onwukwe, 2012: 21). 
c. Oxymoron- According to Crystal (1997) in Onwukwe (2012: $21)$, oxymoron is when two semantically incompatible expressions are placed side by side, thus forming a non-literal interpretation. For example, 'delicious torment', 'living death', etc.

\section{Data Presentation and Analysis}

The data illustrate cases of linguistic deviation in two poems, Soyinka's (1976: 119) 'Night' and 'Death in the Dawn' (1967: 64). The data are organized according to the linguistic levels they represent; lexical, syntactic and semantic levels. For 'Night', the notation ' $\mathrm{N}$ ' is used while for 'Death in the Dawn', 'DD' is used. It should be noted that features at one level may reinforce or explain features at another level. By 'features', is meant those words, lines, or structures in the poem that immediately set apart a particular style. Such features are said to be stylistically significant features of the text.

All the data are analyzed descriptively. Data are presented by writing down deviant lexical items and structures present in the poems; and they are analyzed using some aspects of Niazi \& Gautam's (2010) framework, as well as Onwukwe's (2012) concept of foregrounded irregularities at the lexical, syntactic and semantic levels discussed in the theoretical framework. The data presentation at each level is followed by an analysis.

\section{Data Presentation of Lexical Deviation}


The following are examples of lexically deviant words from the poems. They illustrate deviated use and meaning from the known norm.

(1) sands (N, stanza 3, line 8)

(2) $\operatorname{misted}(\mathrm{N}$, stanza 5 , line 14$)$

(3) dog-nose (DD, stanza 1, line 3)

(4) Cottoned (DD, stanza 2, line 6)

The poet lexically deviated from the two poems equally. There are two instances of lexical items deviating from the known rules by violating the class to which they belong. The other two are instances of deviation from word formation: inflection and compounding.

\section{Data Analysis of Lexical Deviation}

(1) is conventionally supposed to be an uncount noun with no inflection, but instead, the poet attached a suffix (the plural suffixs) to the word possibly to create emphasis, making it a count noun. This also is not seen in the vocabulary of the language. (2) is a lexical item of the language which violates its class; it is a verb used as an adjective of the noun 'calls' in the poem possibly to relate to an unclear concept. (3) is a word (compound) formed from compounding two nouns; may be non-existent in the vocabulary of the language and it is created by the poet to create a relationship between the moisture of the earth and that of a dog's nose. (4) is a lexical item present in the lexicon of the language, but it violates the class to which it belongs. It is a verb used as an adjective of the noun 'feet' and it is likened to the noun 'cotton' in terms of meaning, probably to show how soft the feet is.

\section{Data Presentation of Syntactic Deviation}


The following are examples of syntactically deviated structures from the poem. They illustrate cases of category rule violation and selectional restriction rule (collocational violation). There is also an instance of ungrammaticality.

(5) Your hand is heavy, Night, upon my brow. (N, stanza 1, line 1)

(6) I saw your jealous eye quench the sea's

Fluorescence (N, stanza 2, line 5-6)

(7) dance on the pulse incessant

Of the waves. (N, stanza 2-3, line 6-7)

(8) Night, you rained

Serrated shadows through dank leaves. (N, stanza 3-4, line 9-10)

(9) Sensations pained me, faceless, silent as night thieves. (N, stanza 4, line 12)

(10) These misted calls will yet

Undo me; naked, unbidden, at Night's muted birth $(\mathrm{N}$, stanza 5, line 14-15)

(11) Let sunrise quench your lamps. (DD, stanza 2, line 4)

(12) Not twilight's death and sad prostration. (DD, stanza 2, line 8)

(13) Racing joys and apprehensions (DD, stanza 2, line 10)

(14) A naked day. (DD, stanza 2, line 11)

(15) To wake the silent markets (DD, stanza 2, line 13)

(16) When the road waits, famished. (DD, stanza 3, line 25)

(17) The wrathful wings of man's progression... (DD, stanza 4, line 31)

(18) Silenced in the startled hug of

Your invention (DD, stanza 5, line 33-34)

There are more instances of syntactically deviant structures gotten from 'Death in the Dawn'. They whole data under syntactic 
deviation were instances of selectional restriction (collocational violation) except one which is an instance of category rule violation. There is also an instance of ungrammaticality. The way the structures violated the selectional restriction rule was explained using the [+animate] and [-animate] feature.

\section{Data Analysis of Syntactic Deviation}

(5), (6) and (7), gives 'Night', which has the feature [-animate], the feature [+animate] [+human] and these are instances of instances of selectional restriction (collocational violation). (5) sees 'Night' as something that possess a feature only humans do, 'hand'. (6) sees 'Night as something that possess the feature of an 'eye' and as something that is able to get jealous. (7) sees 'Night' as something that can dance. In (8), the verb 'rained' doesn't go with the noun 'shadows' but rather goes with 'water', and 'Night' cannot perform the action 'rained'; these are instances of selectional restriction. (9) is an ill-formation of the sentence and it can be seen as ungrammatical.

Also, 'sensations' is given the [+animate] feature when it is seen as something that could be silent; instance of selectional restriction. (10) is another instance of selectional restriction as can be seen with the verb 'misted', which has moisture attached to it, selecting the lexical item 'calls'. 'Misted' is also a word which portrays an instance of category rule violation as it violates the class to which it belongs; it is a verb functioning as an adjective in the poem. Also, 'Night' is seen as [+animate] that can be given birth to. In (11), 'sunrise' which has the feature [-animate] is viewed as one with the feature [+animate] which can perform the verb 'quench', an example of selectional restriction. In (12), 'twilight' which has the feature [-animate] is seen as one with the feature [+animate] which can die and assume the position of a sad 
prostration, an instance of selectional restriction. In (13), 'joys' and 'apprehensions' which are also [-animate] are seen as ones with the feature [+animate] which can race, an example of selectional restriction. In (14), 'day' [-animate] is given the attribute [+animate] because it selects the lexical item 'naked', an instance of selectional restriction. In (15), 'markets', [-animate], is given the attribute, [+animate], when in the poem, it can awaken, an example of selectional restriction.

In (16), the road, [-animate], which selects the lexical item, 'famished', is now regarded as one with the feature [+animate] because it can be seen as something that can be very hungry, an instance of selectional restriction. In (17), 'man's progression' [animate], which selects the lexical item, 'wings', is now perceived as [+animate], an example of selectional restriction. In (18), an 'invention' [-animate], takes up the feature [+animate], when it is seen as something that can perform the action 'hug'; an instance of selectional restriction.

\section{Data Presentation of Semantic Deviation}

The following are examples of semantically deviant structures in the poems. They illustrate deviant meanings which gives rise to figures of speech.

(19) Your hand is heavy, Night, upon my brow. (N, stanza 1, line 1)

(20) 1 bear no heart mercuric like the clouds (N, stanza 1, line 2)

(21) Woman as clam (N, stanza 2, line 4)

(22) I saw your jealous eye quench the sea's

Flourescence (N, stanza 2, line 5-6)

(23) dance on the pulse incessant

Of the waves. (N, stanza 2, line 6-7) 
(24) And I stood, drained

Submitting like the sands (N, stanza 3, line 7-8)

(25) Sensations pained me, faceless, silent as night thieves. (N, stanza 4, line 12)

(26) Let sunrise quench your lamps. (DD, stanza 2, line 4)

(27) Racing joys and apprehensions (DD, stanza 2, line 10)

(28) A naked day. (DD, stanza 2, line 11)

(29) To wake the silent markets - (DD, stanza 2, line 13)

(30) When the road waits, famished. (DD, stanza 3, line 25)

(31) The wrathful wings of man's progression... (DD, stanza 4, line 31)

There are more instances of semantically deviant structures gotten from 'Night'. Most of the structures give rise to personification. The others give rise to simile and one gave rise to oxymoron.

\section{Data Analysis of Semantic Deviation}

In the above sentences, meaning is foregrounded and this brings about figurative language. In (19), 'Night' is perceived as [+animate] and this gives rise to personification. From the meaning of the structure, the poet possibly tries to say that when night comes, the reader feels sleepy, his/her eyes begin to close. In (20), there is a comparison made between 'heart' and 'the clouds' using 'like' and this gives rise to simile. In (21), there is a comparison made between 'woman' and 'clam' (a large shellfish that can be eaten) using 'as' possibly to state that a woman behaves like a clam in some way. This gives rise to simile. In (22), 'Night' is given a human attribute whose 'jealous eye' can 'quench' the sea's flourescence. This gives rise to personification. This structure may be used to mean how 'Night' comes with the passing of the sun which lights up the sea and makes it sparkly. In (23), 'Night' is 
also given a human attribute that can 'dance'. This also gives rise to personification. This may also be used to mean how the waves of the sea are dark. In (24), there is a comparison made between the readers' 'way of submission' and 'the sands' using 'like' which may be one of total submission possibly with the way sand submits to the wind.

This gives rise to simile. In (25), there is a comparison made between 'faceless and silent sensations' and 'night thieves' using 'as' which may mean how we have unexpected feelings and this gives rise to simile. In (26), 'sunrise' is given the attribute of a human who can 'quench' something and this gives rise to personification. This structure may stand to mean that with the coming of the sun, lamps which are used in the dark are no longer needed. In (27), 'joys' and 'apprehensions' assume the feature of a human who can 'race' and thus gives rise to personification. This structure may be used to mean how the reader's mind is thinking fast and is not certain about how the day ahead will be. In (28), 'a day' is seen as a human who can be 'naked', thus, gives rise to personification. This may stand to mean a new day that has not yet had any events recorded in it or that hasn't been clothed with any events yet.

In (29), the 'markets' can be seen as an entity bearing the feature [+animate] which can be awoken and this gives rise to personification. It can also be seen as an instance of oxymoron with the two semantically incompatible expressions, 'silent market', placed side by side. They are semantically incompatible because in the real world, a market is usually very noisy. The whole structure may entail the beginning of activities in the market with the start of a new day. In (30), 'the road' is seen as an entity with the [+animate] feature which can get 'famished' and this gives rise to personification. The structure may mean that the road 
hasn't had any record of an accident that cost people their lives for the day and may possibly be waiting for one to occur. In (31), 'man's progression' can be seen as an animate entity that has 'wings' and this gives rise to personification. The structure may mean that man can go to any length and do anything, good or bad, to progress in life.

\section{Conclusion and Recommendation}

This work has handled the linguistic study of Wole Soyinka's 'Night' and 'Death in the Dawn'. It has buttressed the fact that Soyinka's works are creative although his use of language can be complex sometimes. Soyinka in his quest for style deviated from the known linguistic norms at the levels discussed to create effect as can be seen. The choice of words is very important and is capable of expressing effectively the thoughts, feelings and emotions of the poet and passing across the intended message of the writer to the reader of the work. This work has shown that there is a distinction between a linguistic stylistic analysis and a stylistic analysis, poetic and non-poetic language as a means of defining literature. The language used in the two poems discussed in this study is manipulated in ways that signal it as different from 'ordinary language'. The product of this manipulation should not be seen as errors but as the writers' style.

Nneoma Udeze

Department of Linguistics

Nnamdi Azikiwe University, Awka

\section{Chinenye Udeze}


Department of Nigerian languages

Alvan Ikoku Federal College of Education, Owerri

\&

Orji Dereck-M.A

Department of Linguistics

Nnamdi Azikiwe University, Awka

\section{References}

Abrams, M. H. 1981. A glossary of literary terms. New York: Holt, Rinehart and Winston.

Adejare, Oluwole. 1992. Language and style in Soyinka: A systematic text and linguistic study of literary dialect. Ibadan: Heinemann Educational Books.

Anagbogu, Philip N., Mbah, M. B. \& Eme, Cecilia. A. 2001. Introduction to linguistics. Awka: J. F. C. Limited.

Ayeomoni, N. 2003. The role of stylistics in literary studies. IleIfe: Obafemi Awolowo University Press.

Carter, R. 1988. What is stylistics and why do we teach it in different ways? London: Longman.

Crystal, David. 2008. A dictionary of linguistics and phonetics. Oxford: Blackwell Publishing Ltd.

Finch, Geoffrey. 2000. Linguistic terms and concepts. New York: Palgrave.

Ike, Ndubuisi J. 2005. Stylistics of English. Abuja: Wilbest Educational Publishers.

Lawal, R. A. 1997. Stylistics in theory and practice. Ilorin: Paragon Books. 
Leech, Geoffrey \& Short, Mick H. 2007. Style in fiction: A linguistic introduction to English fictional prose. Great Britain: Pearson Education Limited.

Malmkj $\square$, Kirsten. 2002. The linguistics encyclopedia. London and New York: Routledge.

Niazi, Nozar \& Gautam Rama. 2010. How to study literature: Stylistic and pragmatic approaches. New Delhi: PHI Learning Private Limited.

Nwoga, Donatus I. 1967. West African Verse. U. K.: Longman Group Limited.

Onwukwe, Ekwutosi. 2012. An introduction to general and literary stylistics. Owerri: Alphabet Nigeria Publishers.

Sebeok, T. A. 1964. Styles in language. Cambridge, Massachusetts: The Massachusetts Institute of Technology Press.

Senanu, K. E. \& Vincent T. 1976. A selection of African poetry. Great Britain: Longman Group Limited.

Syal, Pushpinder \& Jindal, David. 2010. An introduction to linguistics: Language, grammar and semantics. New Delhi: Prentice Hall of India.

\section{Internet sources}

Nordquist, Richard. 2015. Stylistics (language): Glossary of grammatical and rhetorical terms. http://grammar.about.com/od/rs/g/stylistics-term.htm.

Robbins, Dorothy E. 1997. Is it poetry or prose? http://www.artsreformation.com/a001/dr-prose.html. UKEssays. 2015. Study of the foregrounding theory English language essay. http://www.ukessays.com/essays/englishlanguage/study-of-the-foregrounding-theory-englishlanguage-essay.php. 


\section{Appendix}

Night

Your hand is heavy, Night, upon my brow,

I bear no heart mercuric like the clouds, to dare

Exacerbation from your subtle plough.

Woman as a clam, on the sea's crescent

5 I saw your jealous eye quench the sea's

Flourescence, dance on the pulse incessant

Of the waves. And I stood, drained

Submitting like the sands, blood and brine

Coursing to the roots. Night, you rained

10 Serrated shadows through dank leaves

Till, bathed in warm suffusion of your dappled cells

Sensations pained me, faceless, silent as night thieves.

Hide me now, when night children haunt the earth

I must hear none! These misted calls will yet

15 Undo me; naked, unbidden, at Night's muted birth.

\section{Death in the Dawn}

Traveller, you must set out

At dawn. And wipe your feet upon

The dog-nose wetness of the earth.

Let sunrise quench your lamps. And watch

$5 \quad$ Faint brush prickling in the sky light

Cottoned feet to break the early earthworm

On the hoe. And shadows stretch with sap

Not twilight's death and sad prostration.

This soft kindling, soft receding breeds

10 Racing joys and apprehensions for

A naked day. Burdened hulks retract, 
Stoop to the mist in faceless throng

To wake the silent markets - swift, mute

Processions on grey byways....

15 On this

Counterpane, it was -

Sudden winter at the death

Of dawn's lone trumpeter. Cascades

Of white feather-flakes ... but it proved

20 A futile rite. Propitiation sped

Grimly on, before

The right foot for joy, the left, dread

And the mother prayed, Child

May you never walk

25 When the road waits, famished.

Traveller, you must set forth

At dawn

I promise marvels of the holy hour

Presages as the white cock's flapped

30 Perverse impalement - as who would dare

The wrathful wings of man's Progression ...

But such another Wraith! Brother,

Silenced in the startled hug of

Your invention - is this mocked grimace

35 This closed contortion - I? 